\title{
裸地砂州への種子定着特性と 植生分布が河床変動の応答に与える影響 \\ THE SETTLING PATTERN OF VEGETATION SEEDS \\ ON ALTERNATE BARE SANDBARS AND THE EFFECT OF CORRESPONDING VEGETATION ON RIVER BED MORPHOLOGY
}

\author{
内田典子 1 - 久加朋子 2 -木村一郎 $3 \cdot$ 清水康行 4 \\ Noriko UCHIDA, Tomoko KYUKA, Ichiro KIMURA and Yasuyuki SHIMIZU

\begin{abstract}
1学生会員 学士（工学）東北大学大学院工学研究科（９980-8579 仙台市青葉区荒巻字青葉 6-6-06)
2 正会員 博士 (工学) 北海道大学大学院工学研究院 ( $\bar{T} 060-8628$ 北海道札幌市北区北13条西 8 丁目)

3 正会員 工博 北海道大学大学院工学研究院 ( $\bar{T} 060-8628$ 北海道札幌市北区北13条西8丁目)

47 エー会員 工博 北海道大学大学院工学研究院（ $\bar{T} 060-8628$ 北海道札幌市北区北13条西8丁目)
\end{abstract}

\begin{abstract}
The objective of this study is to observe the characteristics of lotic seeds distribution on bare sandbars, and to confirm the differences of bed morphology change without vegetation and with vegetation patches on sandbars by means of laboratory experiments and numerical analysis. In the experiments, after sandbars were formed, enough amounts of alfalfa seeds were supplied from the inlet section of the flume. The result of experimental flume tests showed that alfalfa seeds, transported by flow, were settled at the front edge of sandbars during the recession stage of the discharge. This is because, the flow at most downstream areas of sandbars and the front edge of sandbars decreased earlier than that of middle area of sandbars during decreasing of discharge, as shown with the numerical results. This flow causes the specific seeds deposition areas. Those results imply that invading vegetation has specific settling characteristics and make vegetation patches on sandbars.
\end{abstract}

Key Words: seed settling pattern, vegetation distribution, bare sandbar, riverbed morphology

\section{1. はじめに}

植生の河川への侵入は全国的に認められる現象であり， 河積の減少に伴う洪水時の災害リスクの増大や, 流路の 固定化による汇濫原の減少が問題視されている. 北海道 においても, 多数の河川において樹林化の進行が報告さ れており，中でも札内川，豊平川，真駒内川のような市 街地内を流れる河川では樹林化対策にかなりの時間と人 件費が割か子ている. 図-1に北海道・豊平川への植生侵 入のようすを示す.このような北海道で問題となる植生 の大半は, 裸地へと先駆的に侵入するヤナギ類である.

植生が河床変動に与える影響に注目した実験や数值解 析はこれまでに多数報告されている1，2，3)疾ど。これらの 報告では，植生の主な影響として，1）植生は網状流路 の流路本数を減らすこと，2）植生は河岸浸食の速度を 遅くすること，3）植生は流路の横方向移動を励起する こと（蛇行流路の形成），4）植生は蛇行の発達と流路 のショートカットを促すこと等が知られている. また, 近年では植物の成長や死滅まで考慮した植生動的モデル を扱った報告もいくらか存在する4). しかしながら，こ
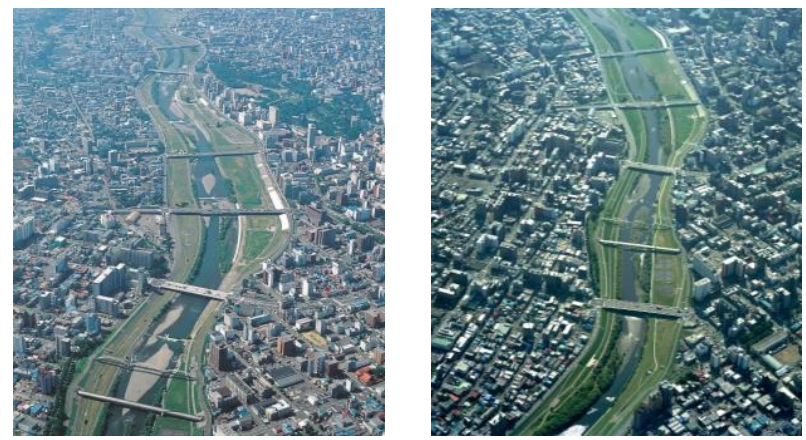

図-1 北海道札幌市内を流れる豊平川（KP15.0付近） への植生侵入の様子, 左）平成12年, 右）平成17年, 札幌開発建設部河川計画課の許可を経て掲載

れらの報告では裸地砂州一の植生侵入の第一段階である 種子の定着特性までは考慮されておらず，種子の定着箇 所の違いに伴う植生分布の違いがその後の河床変動特性 に与える影響については殆ど分かっていない，流水で輸 送される種子の局所的な定着と，それがもたらす植生分 布の違いが河床変動に与える影響を検討した報告は非常 に限られている. 数少ない報告として, Van Dike et al. ${ }^{5}$ は, 高水敷に均等に種子を播いた場合と流水によって種 
子散布した場合の河床変動を実験から比較している. 彼らの報告では，植生が均一に分布する場合，河岸が 安定し, 流路を蛇行させる作用が強く働く. 一方, 植 生が局所的に分布する場合, 砂州の一部でのみ河岸の 安定性が増し, 植生上流部に土砂が堆積するなどか ら, 蛇行流路ではなくIsland Braiding（砂州上に安定し た植生域を有するような複数流路からなる河川）が形 成されること等, 興味深い知見が指摘されている。し かしながら, Van Dike et al. ${ }^{5)}$ の報告においても種子の 定着特性自体までは言及されてはおらず，現時点にお いて砂州形状や増水時の水理条件等の違いが種子の定 着特性に及ぼす影響, あるいはその違いが後の河床変 動に与える影響についてはよく分かっていない.

そこで本研究では, 流水にて輸送される種子の定着 特性とその後の河床変動特性について水路実験と数值 解析から検討した. 将来的に現象を数值モデルへ反映 させることができるように, 水路実験では幅の狭い直 線水路を利用した単純な条件での実験を実施した。 その 後, 砂州上の流れ状況を数值解析にて再現し, 種子が局 所的に堆積する要因について考察すると共に, 植生分布 の違いが異なる河床変動をもたらす可能性について検討 した.

\section{2. 実験方法}

実験には全長 $3.6 \mathrm{~m} ，$ 幅 $0.15 \mathrm{~m}$ ，勾配 $1 / 100$ の長方形矩 形水路を用いた．水路内の河床材料は粒径 $0.78 \mathrm{~mm} の 一$ 様砂とし, 水路上流端より $32 \mathrm{~cm}$ の位置から水路下流端 の砂止め堰まで水路底から $5 \mathrm{~cm}$ の高さで敷きつめた. 水 路下流端には, 出来る限り等流水深を確保するため, 木 製の柵を設置した.

表-1に実験の水理条件を示す．本実験における水理条 件は，黒木・岸の)による交互砂州の形成条件に該当する ように設定した．実験は全てのケースにて流量 $(0.27$ 1/s) を定常給水条件として与え, 実験終盤に種子を散布する 場合のみ実験ケースごとに異なる流量を与えるものとし た．種子には既往検討での利用実績が多いアルファル ファ種子 (長辺 : 1.0 1.2mm程度, 比重 : $1.1 \sim 1.2$ 程度) を用いた．給砂材料は河床材料と同一とし，事前に測定 した平衝掃流砂量に近い量を水路上流域から連続的に与 え続けた.

表-2に実験ケースを示す. Case 1およびCase 2 の初期 河床である交互砂州は，実験開始前に平坦に均した河床 に30分間の通水を行うことで作成した．Case 1では，交 互砂州形成後に定常給水のままで種子を散布し, 種子の 定着位置を確認した。一方, Case 2では交互砂州形成後 の裸地砂州において, 図-2に示寸流量減水条件のもとで 種子を散布し，植生の定着位置をCase 1 と比較した. 図 -2に示寸流量減水条件は, 30 秒程度で水路上流端から与 えた種子が水路下流端まで十分到達寸るため，ポンプを
表-1 実験の水理条件

\begin{tabular}{|c|c|}
\hline \multicolumn{2}{|c|}{ 実験条件 } \\
\hline \hline 流量 $Q\left(\mathrm{~m}^{3} / \mathrm{s}\right)$ & 0.00027 \\
\hline 水路幅 $B(\mathrm{~m})$ & 0.15 \\
\hline 水路勾配 $I$ & 0.01 \\
\hline 河床材料の平均粒径 $d_{m}(\mathrm{~mm})$ & 0.78 \\
\hline 等流水深 $H_{0}(\mathrm{~cm})$ & 0.8 \\
\hline 無次元限界掃流力 $\tau^{*}$ & 0.08 \\
\hline$B I^{0.2} / H_{0}$ & 5.5 \\
\hline
\end{tabular}

表-2 実験ケース

\begin{tabular}{|c|c|c|c|}
\hline ケース & 種子散布 & $\begin{array}{l}\text { 流量 } \\
\left(\mathrm{m}^{3} / \mathrm{s}\right)\end{array}$ & $\begin{array}{c}\text { 実験開始時の植生 } \\
\text { の有無 }\end{array}$ \\
\hline Case 1 & \multirow{2}{*}{ 有 } & 0.00027 & \multirow{3}{*}{ なし } \\
\hline Case 2 & & $0.00027 \sim 0$ & \\
\hline Case 3 & \multirow{2}{*}{ 無 } & \multirow{2}{*}{0.00027} & \\
\hline Case 4 & & & \multirow{2}{*}{ あり } \\
\hline Case 5 & 有 & $0.00027 \sim 0$ & \\
\hline
\end{tabular}

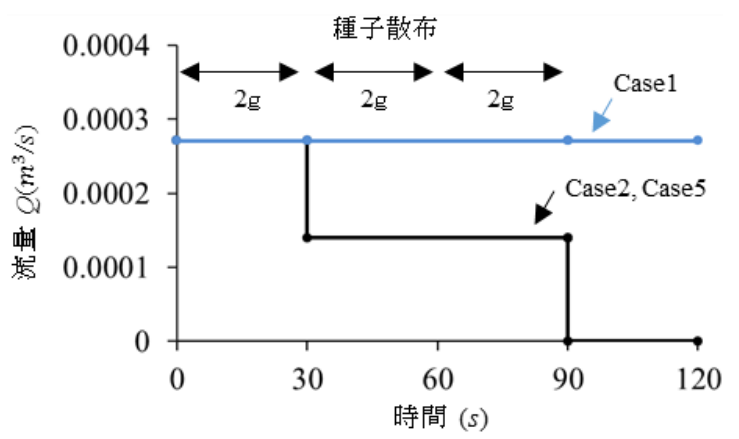

図-2 種子散布位時（Case 1, Case 2, Case 3）の流量

2台使用して1台ずつ止めたものである. 種子の散布は水

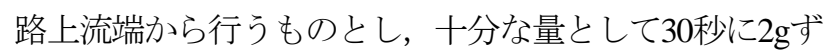
つ（計6g）アルファルファの種子を散布した.

次いで，河床変動応答実験としてCase 3およびCase 4 を実施した. Case 3ではCase 1 終了後に通水を再開し, 30分経過後の砂州の移動と波高の変化等を確認した.

Case 4は, Case 2 終了後に定着した種子が発芽後十分に 成長した 5 日後に通水を再開し，砂州の移動，波長，波 高等の変化をCase 3 と比較した. さらにCase 5 では, Case 4終了後, 図-2に示寸流量減水条件のもとで種子を散布 し, 植生が既に存在する砂州への種子の新規定着位置を 確認し, Case 2と比較した.

\section{3. 実験結果と考察}

\section{（1）裸地砂州へのアルファルファ種子の定着特性}

水路上流から $2 つ$ 目に位置する砂州を測定箇所として 用いた．対象とした交互砂州の波長は約 $1.5 \mathrm{~m} ，$ 波高は約 $0.7 \mathrm{~cm}$ であった.

図-3にCase 1，Case 2およびCase 5終了時の河床と種子 の堆積の様子を示寸. 図-3（a）より, 定常洪水条件にお いて種子を散布した場合, ほぼすべての種子は下流端ま で流下し，砂州上に種子が定着しなかった。これは， 

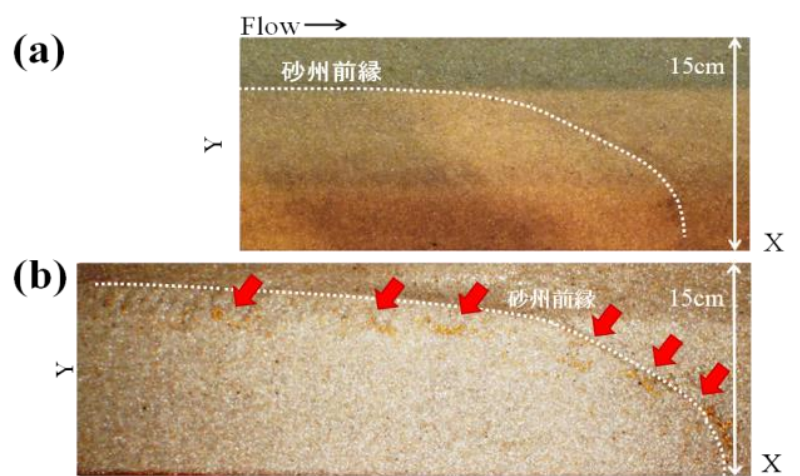

(c)

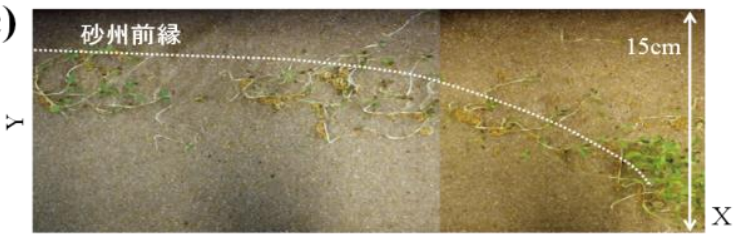

図-3裸地砂州への種子定着状況の比較
a) Case 1
b) Case 2 (赤矢印で示す黄土色の点が種子である),
c）Case 5 (植生周りの黄土色の点が種子である)

Case 1の定常給水条件の場合, 砂州はすべて冠水状態と なり，砂州上を流れる水の流速が速いために種子が定着 しにくい状況が作られたと考えられる。一方，図-3 (b) より, 流量減水条件において流水にて運ばれる種子の存 在を考慮した場合，散布した種子は砂州上に均等に定着 するのではなく，砂州前縁部にのみ集中的に定着した。 これは，図-4に示すように砂州前縁部は横断方向の河床 位高が急に変化するため，減水中に種子が堆積しやすい 状況が創出されるためと考えられる.

さらに, 図-3 (c) より, 植生の存在する砂州に種子を 散布したCase 5では，種子はCase 2 と同様に砂州全体に 均等に定着せず，植生の集中する砂州前縁部にの久集中 して種子が定着する様子が確認された，以上のことから， 今回対象としたような流路幅の制限された水路内に形成 されるような交互砂州では, 流水性の植物の種子は砂州 前縁に集中して定着する可能性が高いこと，および後か ら定着する種子も先に砂州上で成長している同一種と同 じく砂州前縁に定着寸る可能性が高いことが推察される。

\section{（2）植生の有無に伴う河床変動}

図-5にCase 3およびCase 4実施前後の河床高の縱断変 化を示す. 図-6にCase 4実施前後の河床高の横断変化を 示す．図-5より，砂州上への植生の有無の違いによる河 床変動を比較すると，砂州上に植生がなかったCase 3で は図-5（a）に示すように砂州が下流へと明瞭に伝播した。 一方，図-5（b)より，砂州前縁部に植生が繁茂していた Case 4ではCase 3と異なり砂州の前進が殆ど認められず, 砂州前縁部の河床高が顕著に上昇していた。また図-6よ り，横断方向の河床高さも図-5 (b) に示寸縦断方向の河 床高さと同様に，砂州前縁部において河床が上昇したこ
とが分かる.これらは，植生が流れの抵抗として働くた め，砂州前縁部にて掃流砂が捕捉されて河床が高くなっ たものである。

\section{4. 数値解析}

実験で確認された流水で輸送される種子の裸地砂州一 の定着特性と流況特性との関係性，および植生繁茂状況

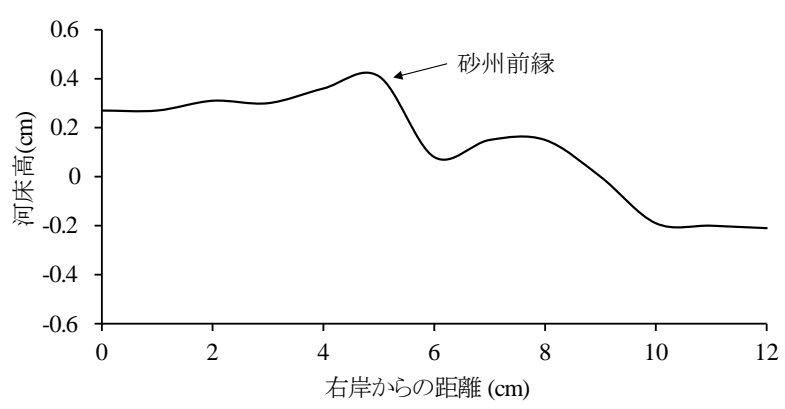

図-4 Case 1の横断方向の河床位 （砂州の横断幅が最も広い箇所にて測定）

(a)

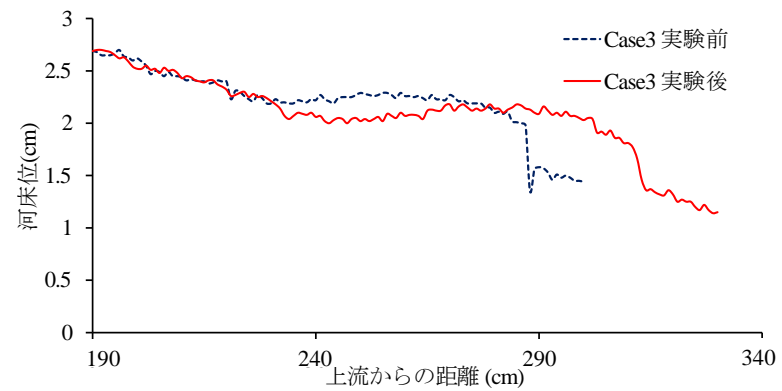

(b)

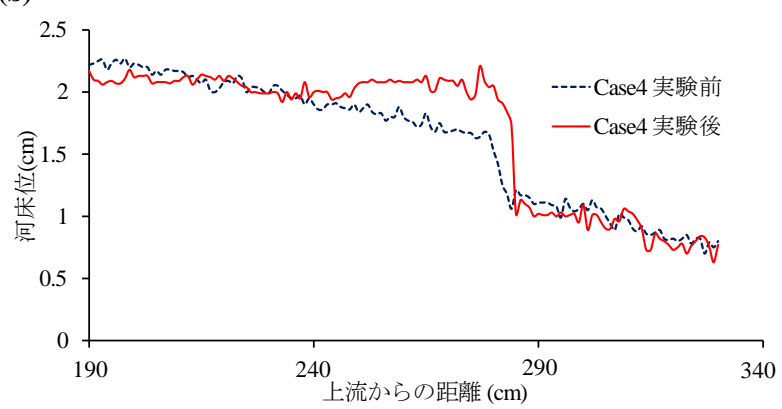

図-5 植生の有無に伴う河床位の縦断方向変化 a) Case 3, b) Case 4

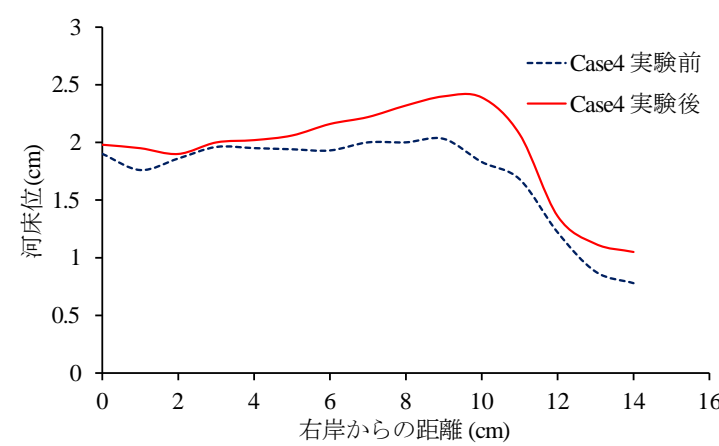

図-6 Case 4における砂州の河床位の横断方向変化 
の違いが河床変動計算に与える影響を検討するため，以 下の解析を実施した。

\section{（1）数值解析法}

流れの計算は水深平均された平面二次元流れの支配方 程式を用いる．ただし，運動方程式には水中の植生の影 響を以下のように抗力の形で考慮している.

$$
\begin{aligned}
\frac{\partial(h u)}{\partial t}+ & \frac{\partial\left(h u^{2}\right)}{\partial x}+\frac{\partial(h u v)}{\partial y}=-g h \frac{\partial H}{\partial x}-\frac{\tau_{b x}}{\rho} \\
+ & \frac{\partial}{\partial x}\left(v_{t} \frac{\partial(h u)}{\partial x}\right)+\frac{\partial}{\partial y}\left(v_{t} \frac{\partial(h u)}{\partial y}\right)+F_{v x} \\
\frac{\partial(h v)}{\partial t}+ & \frac{\partial(h u v)}{\partial x}+\frac{\partial\left(h v^{2}\right)}{\partial y}=-g h \frac{\partial H}{\partial y}-\frac{\tau_{b y}}{\rho} \\
& +\frac{\partial}{\partial x}\left(v_{t} \frac{\partial(h v)}{\partial x}\right)+\frac{\partial}{\partial y}\left(v_{t} \frac{\partial(h v)}{\partial y}\right)+F_{v y}
\end{aligned}
$$

ここに, $t$ は時間， $x, y$ は流下方向軸と横断方向軸， $h$ は水深, $u, v$ は水深平均流速の $x, y$ 方向成分, $g$ は重力 加速度, $H$ は水位， $\tau_{b x}, \tau_{b x}$ はせん断力の $x, y$ 方向成分, $\rho$ は水の密度である. $v_{t}$ は乱流拡散計数であり本計算で は0方程式モデルを用いている， $F_{x} ， F_{y}$ は植生の影響を 表す抗力であり, 本計算では以下の式より求めている.

$$
\begin{aligned}
& \frac{F_{v x}}{\rho}=\frac{1}{2} C_{d} \lambda_{v} h u \sqrt{u^{2}+v^{2}} \\
& \frac{F_{v y}}{\rho}=\frac{1}{2} C_{d} \lambda_{v} h v \sqrt{u^{2}+v^{2}}
\end{aligned}
$$

ここに, $C_{d}$ は形状抗力係数， $\lambda_{v}$ は植生密生度である. 流れの計算の基礎式の差分にはMacCormackの陽的・2段 階差分法を適用し, 数值不安定性を抑制するため CausionモデルのTVD項を付加している.

河床近傍の流速は, 水深平均流速の流線の曲率より予 測する. 流線の曲率を求める際の係数值はEngelund ${ }^{7)}$ と 同様の7.0を用いている. 流砂は掃流砂のみを考慮し, 芦田・道上式 ${ }^{8)}$ に河床の局所的な勾配が流砂ベクトルに 及ぼす影響を考慮した芦田・江頭・劉 9)の方法を用い る. 河床変動計算では, 局所河床勾配が安息角以上に なった場合，勾配の高い計算メッシュから砂を低いメッ シュに落とし，局所勾配が安息角以上にならないように 補正している。 なお，本計算では植生繁茂に伴う安息角 変化は不明瞭なため考慮せず，安息角を常に45度の一定 值として扱っている.

\section{(2) 解析条件}

数值解析における計算領域は, 水路実験と同じ全長さ $3.6 \mathrm{~m}$, 幅 $0.15 \mathrm{~m}$, 勾配 0.01 の直線矩形水路とした。数值 解析の初期河床は平坦床であるが，水路実験と同様に始 めに30分間定常流を与え，水路内に交互砂州を形成させ， 以下に述べる解析ケースの初期河床とした.

表-3に解析条件を示す. Case S1は，水路実験Case 1 と
表-3 解析ケース

\begin{tabular}{|c|c|c|c|}
\hline ケース & 植生の有無 & 流量 $\left(\mathrm{m}^{3} / \mathrm{s}\right)$ & 植生密度 \\
\hline \hline Case S1 & なし & 0.0027 & - \\
\cline { 1 - 3 } Case S2 & なし & $0.0027 \sim 0.0$ & - \\
\hline Case S3 & $\begin{array}{c}\text { 植生あり } \\
\text { Case S4 }\end{array}$ & 0.0027 & - \\
\hline (砂州前縁部のみ繁茂) & 0.0027 & 0.1 \\
\hline Case S5 & $\begin{array}{c}\text { 植生あり } \\
\text { (砂州上に均等に繁茂) }\end{array}$ & 0.0027 & 0.02 \\
\hline
\end{tabular}

同様に砂州全体が冠水する流量の定常流を与え，砂州上 の流況特性を確認するものである. Case S2は，流量減 少時の砂州上の流れ場を検討するものであり，90秒かけ て流量が線形的に減少するハイドログラフを与えている. Case S3, Case S4, Case S5植生が河床変動に与える影響 を比較するものである. 解析対象区間は実験と同じく水 路中央部付近に形成された砂州を対象とした。 Case S3 は植生なしの交互砂州, Case S4は実験結果と同じく植 生を砂州前縁にのみ分布させるケース, Case S5は砂州 全体に一様に植生を分布させるケースである.ただし, Case S4 と Case S5では砂州上の植生分布域が異なるもの の，一つの砂州上における植生の総量が同じ值となるよ うに植生密度を調整した。

\section{5. 解析結果と考察}

\section{（1）砂州上の流況特性}

図-7は，数值解析の初期河床として得られた交互砂州 の河床位を，水路右岸から $2 \mathrm{~cm}$ 離れた縦断面において 実験值と比較したものである. 図-7によると，数值計算 にて計算された交互砂州は水路実験よりもやや波高が低 いものの河床の縦断変化特性は大まかに表現できており， ここでの解析に必要な精度が得られていると判断できる。 図-8にCase S1の解析で得られた河床位および水深平均 流速ベクトルを示す. 図-8の赤矢印は，砂州上の水深平 均流速ベクトルの主な移動方向を示している. 図-8に示 すとおり，砂州全体が水に浸かっている状況では，砂州 上には比較的速い流れが形成されることがわかる.この ため，水路実験のCase 1のように高水敷が水に浸かる間 は，種子は上流から輸送された流れにのって下流へと運 ばれ，種子は砂州上に堆積しない，図-9に非定常の流量 減水条件を用いたCase S2の河床位コンター図および水

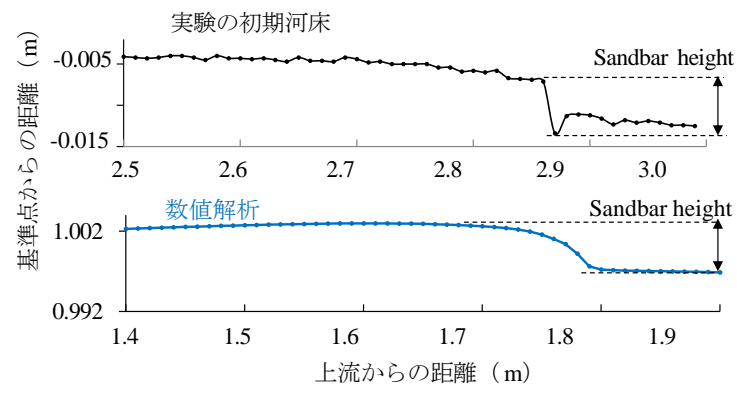

図-7＼cjkstart右岸から2cmの縦断面における河床位の縦断変化 


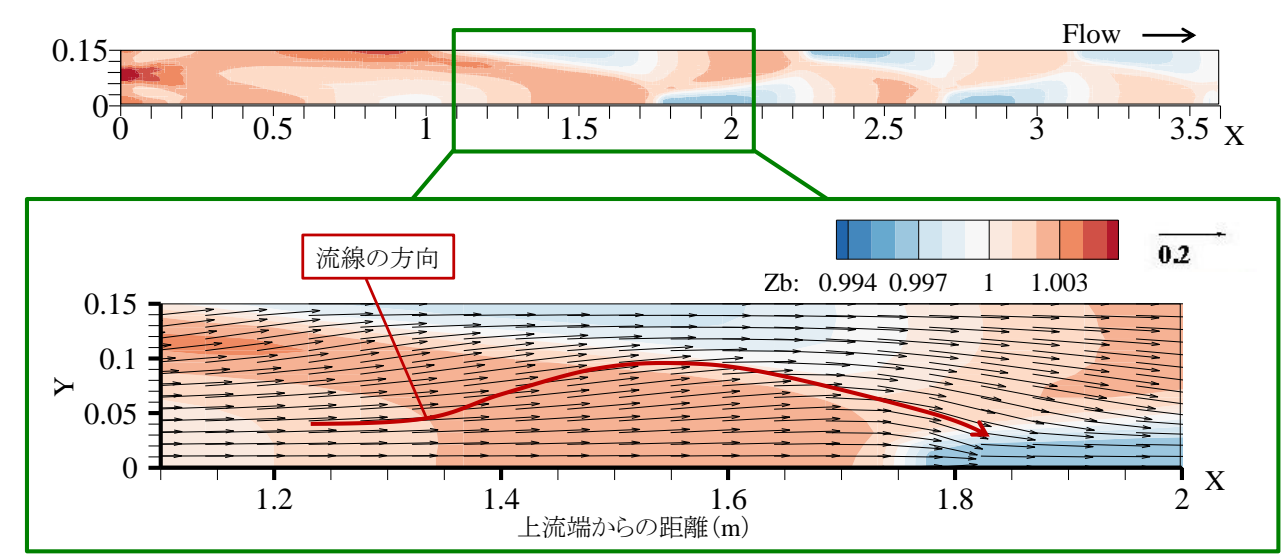

図-8 河床位および水深平均流速ベクトル(Case S1)

深平均流速を示す. また, 図-10に縦断方向の河床位お よび流量減少に伴う水面形変化を, 図-11に砂州の横断 方向の河床高を示寸．図-9より，本検討で対象とするよ うな水路幅の固定された直線水路に形成される交互砂州 上では，流量減水時，図-9 (b) に示寸ように砂州下流域 から水深平均流速が低下寸ることがわかる．これは，砂 州上の流れは図-9 (b) の赤矢印で示されるように砂州の 最下流域よりも上流側にて主流路に向かって流れ込むた めである.このため, 図-10に示すように砂州下流域で は流量低下の早い段階から水位が低下し，上流から輸送 されてきた種子, あるいは浮遊砂のような物質が堆積し やすい状況になるものと考えられる. 次いで, 流量がさ らに減少すると図-9（c)および図-9（d）に示すように, 水深平均流速は砂州前縁部において砂州中央部よりも先 に低下寸る．これは，図-11および実験結果（図-4）か らも示されたように，直線水路に形成される交互砂州の 横断河床位は砂州中央部から砂州前縁に向かって高くな

(a) $\mathrm{T}=1800 \mathrm{~s}$

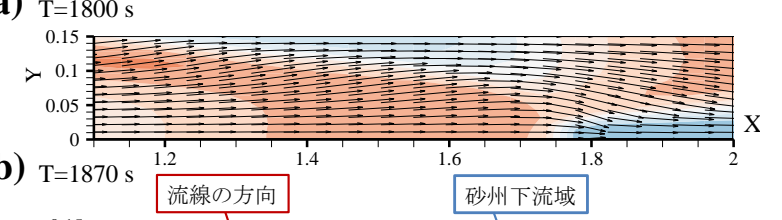

(c)
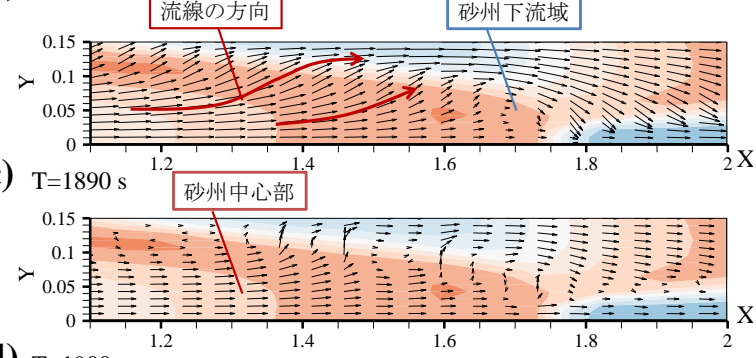

(d) $\mathrm{T}=1900 \mathrm{~s}$

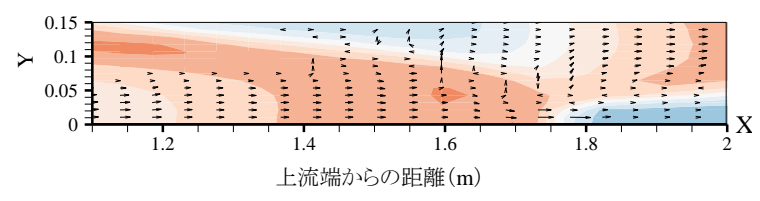

図-9 流量減少時の水深平均流速ベクトル (Case S2), (b) 〜 (d) で見られるX=1. 6mあたりの河床高変化は 流量減少に伴う掃流砂の堆積によるものである.
るためである. 以上の流況特性より，本実験条件下では 上流から輸送されてくる種子は流速の速い砂州中央部に は堆積し難く, 流量減少時に砂州下流域および砂州前縁 部まで運ばれそこで堆積する，もしくは砂州中央部から 主流路へと流され，さらに下流へと輸送されることとな る.

\section{（2）植生分布の違いによる河床変動}

図-12にCase S3, Case S4, およびCase S5の河床変動計算 の結果を示寸. 図-12より植生の有無と植生繁茂状況の違 いに対する河床変動を比較すると, 砂州上に植生が存在 しないCase S3では, 図-12 (a) より計算終了時の砂州が計 算開始時とほぼ同じ形を保って下流方向へと伝播してい る. その一方, 図-12 (b) および図-12 (c)によると, 砂 州上に植生を有するCase S4およびCase S5では砂州の河床 上昇が認められる. これは, 植生によって砂州上の流れ の抵抗が増し，植生近傍に掃流砂が捕捉されや寸くなっ たためである。

次いで，図-12（b)および図-12（c）の河床変動と比較 すると，植生を砂州前縁にの久集中させたCase S4では, 植生を砂州全面に分布させたCase S5に比べて河床上昇の 割合が少ないことがわかる. さらに, Case S4では砂州上 に局所的な河床上昇の場（赤矢印で示寸）が認められる. これは, Case S4では, 植生によって流れの抵抗が砂州の 一部のみで急激に上昇寸るため, 上流から流れてきた掃 流砂が局所的に堆積しや寸くなるためである. なお，こ のような裸地砂州上に形成される局所的な植生繁茂に伴 う局地的な河床上昇は, 始めに述べた通り Van Dike et al. ${ }^{5)}$ においても報告されている，彼らの報告では，このよう な植生に伴う局所的な河床上昇は網状河川が完全な蛇行 河川へと移行することを妨げ, Island Braiding 形状をもた らすなど，植生が砂州全面に存在する場合と異なる河床 変動を引き起こすことが指摘されている. 本検討では側 壁を固定させた条件で河床変動計算を行っているため, 植生繁茂条件の違いが流路の蛇行形成に与える影響まで を考察することは出来ないが, 図-10よりCase S3, Case 


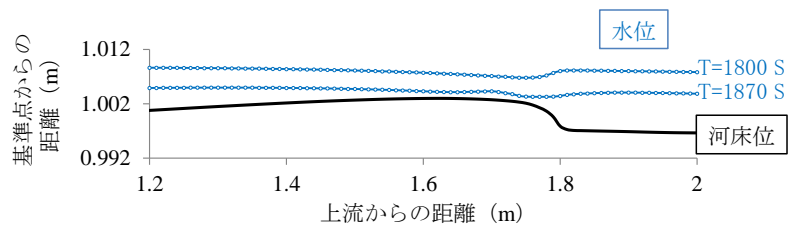

図-10＼cjkstart右岸から2cmの縱断面における河床位と 水面形変化 (Case S2)

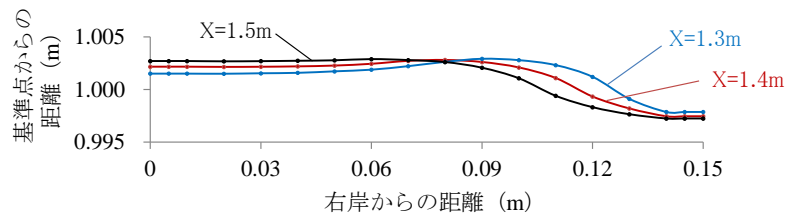

図-11＼cjkstart横断面における河床位高さ（Case S2）， 図中のXは上流端からの距離を示す .

S4，Case S5の主流路内の局所洗掘位置を比較すると， 局所洗掘域は砂州前縁の河床位が高くなるほど下流側 へと移動することがわかる.このような河床変動特性の 違いは，側壁を侵食性河岸である水路実験や数值計算を 行った場合, その後の河床変動に大きな違いを引き起こ 寸要因となる可能性が推察される。

\section{5. 結論}

本研究では，水路実験にて流水にて輸送される種子の 裸地砂州上への定着特性および植生侵入後の河床変動特 性について確認するとともに，数值解析にて砂州上の流 況特性を再現し，種子の定着特性に違いがもたらされる 要因を検討した．また，植生繁茂の場所の違いが河床変 動に与える影響についても非侵食性河岸を有する直線水 路を対象と寸る検討を行った. 本研究で得られた成果を まとめると以下のようである.

（1）水路実験より，流水で輸送される種子は流水減水時 に裸地砂州へと定着すること，およびその定着位置は 一様ではなく，砂州前縁に集中することを確認した。 また, 砂州前縁にて植生が成長した後に水路上流から 再度種子を供給した結果，種子は裸地砂州の場合と同 じく砂州前縁にのみ集中して堆積した。 これは, 流水 にて輸送される種子の定着特性は成長後の同一種の植 生から受ける影響が小さいことを示寸ものである.

（2）数值解析によると, 砂州全体が水に浸かっている状 況では砂州上に比較的速い流れが形成される. 一方, 流量が減少し始めると，まず砂州下流域にて水深平均 流速が低下し，次いで砂州前縁部の水深平均流速砂州 中央部よりも先に低下寸る.これより，上流から輸送 されてくる種子は流速の速い砂州中央部には堆積し難 く, 流量減少時に砂州下流域および砂州前縁部まで運 ばれそこで堆積する，もしくは砂州中央部から主流路 へと流され，さらに下流へと輸送されることとなる.

（3）数值解析による河床変動解析より，植生の分布状況 により異なる河床変動がもたらされることが示唆され (a)

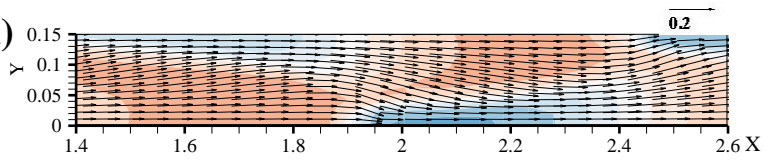

(b)

砂州内部の局所的な河床上昇

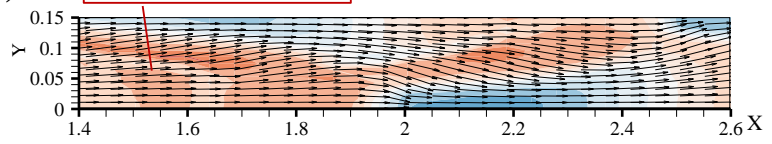

(c)

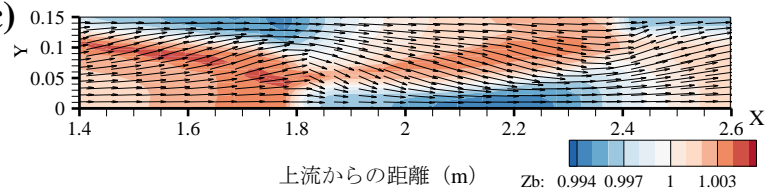

図-12 河床変動および水深平均流速ベクトル,

a) Case S3, 植生なし

b) Case S4，砂州前縁にこのみ植生

c) Case S5, 砂州全面に植生

た．植生を砂州前縁にの夕存在させた場合，砂州上に 局所的な河床上昇域が形成された。一方，砂州全面に 均等に植生を分布させた場合, 砂州前縁部の河床上昇 が最も大きくなり，それに伴い主流路の局所洗掘域は， その他のケースに比べて下流側へと移動した.

\section{参考文献}

1) Tal, M. and Paola, C.: Effects of vegetation on channel morphodynamics: Results and insights from laboratory experiments, Earth Surface Processes and Landforms, Vol.35, pp. 1014-1028, 2010.

2) Jang, C. L., Shimizu, Y.: Vegetation effects on the morphological behavior of alluvial channels、Journal of Hydraulic Research, Vol. 45, pp.763-773, 2007.

3）清水義彦，岩見収二：碟床河床の植生化による砂州・みお 筋の形態変化について, 水工学論文集, Vol.68, I-973-I-978, 2012.

4) 内田崇浩, 木村一郎, 川村里実, 清水康行 : 植生の消長を 考慮した水路における数值解析的研究, 水工学論文 集,Vol.59, pp. I_1147-1152, 2015.

5) Van Dike, W. M., Teske, R., Van de Lageweg, W. I. and Kleinhans, M. G.: Effects of vegetation distribution on experimental river channel dynamics, Water Resources Research, Vol.49, pp. 75587584, 2013.

6) 黒木幹男, 岸力 : 中規模河床形態の領域区分に関寸る理論 的研究, 土木学会論文報告集, Vol.342, pp.87-96, 1984.

7) Engelund, F.: Flow and Bed Topography in Channel Bends, Journal of Hydraulics Division. ASCE, Vol. 100, No. HY11, 1974.

8) 芦田和男, 道上正規 : 移動床流れの抵抗と掃流砂量に関寸 る基䃈的研究, 土木学会論文集, Vol.206, pp.59-69, 1972.

9）芦田和男，江頭進治，劉炳義 : 蛇行流路における流砂の分 級および河床变動に関する数值解析, 水工学論文集, Vol.35, pp.383-390, 1991.

(2015.9.30受付) 